\title{
ECONOMIC FEASIBILITY AND ROTATION AGE FOR STANDS OF CANDEIA (Eremanthus erythropappus)
}

\author{
Carolina Souza Jarochinski e Silva ${ }^{1}$, Antonio Donizette de Oliveira² ${ }^{2}$ José Luiz Pereira de Rezende $^{3}$, \\ José Márcio de Mello ${ }^{4}$ José Roberto Soares Scolforo 5
}

(received: April 19, 2011; accepted: August 31,2012)

\begin{abstract}
Cultivation of nonnative candeia is an alternative way of obtaining raw material to meet the market demands for essential oils and fence posts. A successful stand is conditional on careful planning intended to optimize activities and make the project economically feasible. The objective of this study was to analyze the economic feasibility and to determine the economic rotation age for stands of candeia (Eremanthus erythropappus) using different interrow spacing arrangements, as well as to analyze the sensitivity of both economic indicators for candeia and economic rotation to variations in cash flow variables. Equivalent Annual Value (VAE) was the method used for the economic analyses. A simulation was carried out to detect VAE sensitivity to changes in variables related to cash flow. It was concluded that candeia cultivation can be profitable when spacing arrangements are $1.5 \times 2.0 \mathrm{~m}$ or more. Arrangements denser than that are economically unfeasible for the ages being analyzed. Among the analyzed spacing arrangements, $1.5 \times 3.0 \mathrm{~m}$ was found to be the most profitable and less risky. The economic rotation age for candeia is 15 years using $1.5 \times 1.5 \mathrm{~m}$ spacing; 13 years using $1.5 \times 2.0 \mathrm{~m}$ and $1.5 \times 2.5 \mathrm{~m}$ spacing; and 12 years using $1.5 \times 3.0 \mathrm{~m}$ spacing. Proportional variations in timber price, volume output and interest rate implied inversely proportional variations in economic rotation for the spacing arrangements being studied. Conversely, proportional variations in seedling price implied directly proportional variations in rotation. Changes in land price did not affect economic rotation for any of the spacing arrangements.
\end{abstract}

Key words: Economic analysis, economic rotation, spacing, sensitivity analysis.

\section{VIABILIDADE ECONÔMICAE ROTAÇÃO FLORESTALDE PLANTIOS DE CANDEIA (Eremanthus erythropappus)}

\begin{abstract}
RESUMO: O plantio da candeia é uma fonte alternativa de matéria-prima para suprir a demanda por óleos essencial e moirão de cerca no mercado. Para a obtenção de um plantio bem sucedido é necessário um planejamento criterioso, visando a otimizar as atividades e viabilizar economicamente o projeto. Objetivou-se, com este estudo, analisar a viabilidade econômica e determinar a rotação econômica de plantios de candeia (Eremanthus erythropappus) em diversos espaçamentos e analisar a sensibilidade dos indicadores econômicos do plantio de candeia e da rotação econômica à variações em variáveis relacionadas ao fluxo de caixa. Para as análises econômicas, utilizou-se o método do Valor Anual Equivalente (VAE). Realizou-se uma simulação para detectar a sensibilidade do VAE a alterações em variáveis do fluxo de caixa. Concluiu-se que o plantio de candeia foi lucrativo em espaçamentos estudados iguais ou maiores que 1,5x 2,0 m. Plantios mais adensados são inviáveis economicamente nas idades analisadas. Entre os espaçamentos estudados o espaçamentol,5 x 3,0 m foi o mais lucrativo e o de menor risco. A rotação econômica para a candeia é de 15 anos no espaçamento 1,5 x 1,5 m; 13 anos nos espaçamentos 1,5 × 2,0m e 1,5 × 2,5 me de 12 anos no espaçamento 1,5 × 3,0 m. Variações proporcionais no preço da madeira, produtividade volumétrica e taxa de juros implicaram em variações inversamente proporcionais na rotação econômica dos espaçamentos estudados. Por outro lado, variações proporcionais no preço da muda implicaram em variações diretamente proporcionais na rotação. Mudanças no preço da terra não alteraram a rotação econômica de nenhum espaçamento.
\end{abstract}

Palavras-chave: Análise econômica, rotação econômica, espaçamento, análise de sensibilidade.

\section{INTRODUCTION}

Cultivation of nonnative candeia (Eremanthus erythropappus) is an alternative way of obtaining raw material to meet market demands for its multiple products, including essential oil and fence posts, given that native candeia stands are proving insufficient. A successful stand is conditional on careful planning

\footnotetext{
${ }^{1}$ Forest Engineer, MSc in Forest Engineering - Fibria Celulose S/A - Rodovia ES-010, km 25, s/n - Bairro Barra do Riacho - $29197-551$ Aracruz, ES, Brasil - carolina.silva@ fibria.com.br

${ }^{2}$ Forest Engineer, Professor PhD in Forest Sciences - Universidade Federal de Lavras - Departamento de Ciências Florestais - Cx. P. 3037 -37200-000 - donizete@dcf.ufla.br

${ }^{3}$ Forest Engineer, Professor PhD in Forest Economics - Universidade Federal de Lavras - Departamento de Ciências Florestais - Cx. P. 3037 - 37200-000 - jlpzrezende@ dcf.ufla.br

${ }^{4}$ Forest Engineer, Professor PhD in Forest Resources - Universidade Federal de Lavras - Departamento de Ciências Florestais - Cx. P. 3037 -37200-000 - josemarcio@dcf.ufla.br

${ }_{5}^{5}$ Forest Engineer, Professor PhD in Forest Engineering - Universidade Federal de Lavras - Departamento de Ciências Florestais - Cx. P. 3037 - 37200-000 - jscolforo@dcf.ufla.br
} 
intended to optimize activities and make the project economically feasible.

Financial planning of a project is an integral part of its long-term planning process. Planning entails deciding ahead, in other words, having choice options and consequently having control over potential outcomes (YUH-CHING 2003).

Choice is based on profit prospects, yet accepting a project entails more than merely ensuring positive profit. A project should only be accepted if the price to be paid for it is less than the value of its returns, the determination of which depends on future estimates of revenues, of all costs and of the opportunity cost (LAPPONI, 2007). Therefore, in order to economically evaluate a project, one should consider its cash flow, which is the costs and revenues distributed across the expected lifetime of the project (REZENDE; OLIVEIRA, 2008).

Discounted cash flow methods are widely used in the forestry sector for economic analysis (FIGUEIREDO et al., 2005; GARDINGEN et al., 2003; RODRIGUES et al., 2007; SIREGAR et al., 2007; SOARES et al., 2003; WHITTOCK et al., 2004). These methods are also applied to determine the optimal economic rotation of a stand, in itself another important factor while financially planning forest projects.

Forest rotation, or optimal rotation age, can be defined as the time span between establishment and harvest of a stand, and is often used in forest management plans because it directly affects decision-making among investors (LOPES, 1990). According to Hoffman and Berger (1973), harvesting a forest stand outside the optimal age will entail increased production costs, ultimately preventing maximum return on investment.

Different methods are available to determine the optimal rotation age of a forest. According to Rezende et al. (2005), best known methods include ecological or physical rotation, silvicultural rotation, technical rotation, maximum volume output rotation and economic rotation.

As regards economic rotation, the focus is to maximize profit. According to Rezende et al. (2005), this method is distinguished from the others in that it emphasizes the economic-financial side. Scolforo and Hosokawa (1992) defend this method as being more convenient because it takes into account interest rate, costs and plant size.

Optimal rotation age may be influenced by technical factors such as, for instance, interrow spacing, and/or economic factors such as production costs, timber price and the discount rate used.

Cerne, Lavras, v. 18, n. 4, p. 695-706, out./dez. 2012
Based on the above considerations, this study aimed to analyze the economic feasibility and to determine economic rotation age for stands of candeia (Eremanthus erythropappus) using assorted interrow spacing arrangements, as well as to analyze the sensitivity of economic indicators for candeia and of economic rotation to variations in cash flow variables.

\section{MATERIAL AND METHODS}

\subsection{Study site}

The experiment was conducted in Carrancas, a municipality of Minas Gerais state situated at coordinates $21.48^{\circ} \mathrm{S}$ and $-44.64^{\circ} \mathrm{W}$. It was laid out in a randomized block design and consisted of a candeia stand installed in March 2002, comprising an area of 2.87 ha.

Four blocks were defined, divided into four randomized plots, each with 532 planting holes spread across 14 rows, with the following spacing arrangements: treatment 1 (T1) - $1.5 \times 1.5 \mathrm{~m}$; treatment 2 (T2 ) - $1.5 \times 2.0 \mathrm{~m}$; treatment 3 (T3) - $1.5 \times 2.5 \mathrm{~m}$; treatment 4 (T4) $-1.5 \times 3.0 \mathrm{~m}$.

Fertilization was applied using $100 \mathrm{~g}$ per hole of 414-8 + Zn-0.4\% NPK fertilizer, and topdressing consisted of $30 \mathrm{~g}$ of borax per planting hole. For ant control, granulated bait was used.

\subsection{Estimated timber volume for different stand ages}

Timber volumes for different ages were obtained from a study conducted by Silva (2009), who fitted growth models for several treatments of the experiment. In this study, timber volume was estimated using cubic meter. To convert Table 1 values, which are given as stere meter (st), a 2.67 stack factor was used, as determined by Pérez (2001).

\subsection{Costs and revenues related to candeia production}

Costs related to implementation activities (soil preparation, planting, seedling formation, fertilization, ant control etc.) and maintenance activities (ant control, weeding, etc.) in connection with the candeia stand have been recorded since the establishment of the experiment in 2002. However, values served only as a reference to prepare the cost spreadsheet used in the economic analysis, since, this being an experiment, some values may be overestimated due to more time being required to perform certain activities inherent in the implementation and maintenance of the experiment. 
Table 1 - Timber volume (st/ha) for various ages and treatments.

Tabela 1 - Volume de madeira (mst/ha) para as diversas idades e tratamentos.

\begin{tabular}{ccccc}
\hline $\begin{array}{c}\text { Age } \\
\text { (years })\end{array}$ & $\begin{array}{c}\mathrm{T} 1 \\
(1.5 \times 1.5 \mathrm{~m})\end{array}$ & $\begin{array}{c}\mathrm{T} 2 \\
(1.5 \times 2.0 \mathrm{~m})\end{array}$ & $\begin{array}{c}\mathrm{T} 3 \\
(1.5 \times 2.5 \mathrm{~m})\end{array}$ & $\begin{array}{c}\mathrm{T} 4 \\
(1.5 \times 3.0 \mathrm{~m})\end{array}$ \\
\hline 7 & 52.39 & 54.55 & 47.39 & 49.82 \\
8 & 59.83 & 62.34 & 54.15 & 56.92 \\
9 & 67.28 & 70.09 & 60.90 & 64.03 \\
10 & 74.73 & 77.86 & 67.66 & 71.13 \\
11 & 82.18 & 85.63 & 74.39 & 78.20 \\
12 & 89.63 & 93.37 & 81.11 & 85.31 \\
13 & 97.08 & 101.11 & 87.84 & 92.38 \\
14 & 104.50 & 108.86 & 94.57 & 99.46 \\
15 & 111.93 & 116.60 & 101.30 & 106.53 \\
\hline
\end{tabular}

The cost spreadsheet used in the economic analysis is illustrated in Table 2, developed as follows:

- costs of activities and inputs required to implement a candeia stand (up to age 6 months): obtained by surveying data in the municipalities of Baependi, Caxambu and Carrancas etc., from rural properties participating in the candeia production incentive program sponsored by the State Forest Institute of Minas Gerais (IEF-MG);

- annual maintenance costs until rotation age: estimated by using eucalyptus stand maintenance costs as a reference, since the existing candeia stands are still young and thus available information on annual maintenance of this species is scarce. It is assumed here that candeia maintenance is similar to maintenance of eucalyptus stands intended for energy or pulp production;

- cost of harvest: involves felling, bucking and hauling timber to the nearest accessible forest road: set at $\mathrm{R} \$ 25.18 / \mathrm{st}$, based on a study conducted by Oliveira et al. (2010) dealing with native candeia. To obtain the cost of harvest per hectare for each treatment and age, the above value was multiplied by timber volumes provided in Table 1 ;

- annual cost of land: considered as being the interest on the value of this production factor. Land value was set at $\mathrm{R} \$ 2,500.00 / \mathrm{ha}$, which is the value customarily used in the region.

Revenues were derived by multiplying estimated timber volume for each spacing arrangement at various ages (Table 1) by its sale price hauled to the nearest accessible forest road, set at $\mathrm{R} \$ 130.00 /$ st. This value was obtained through interviews with local farmers in municipalities that sell native candeia timber to oil manufacturers as well as from interviews with managers of candeia oil companies that buy raw material from stands located in Minas Gerais.

\subsection{Economic analysis}

To analyze the economic feasibility of candeia production and to determine the economic rotation age, the criterion Equivalent Annual Value (VAE) or Equivalent Periodic (Cost) Benefit (B(C)PE) was used.

The formula to calculate VAE is given as follows:

$V A E=\frac{V P L . i .(1+i)^{n}}{(1+i)^{n}-1}$

Where

$V P L=\sum_{\mathrm{j}=\mathrm{o}}^{\mathrm{n}} R_{j}(1+i)^{-j}-C_{j}(1+i)^{-j} \sum_{\mathrm{j}=\mathrm{o}}^{\mathrm{n}}$

$C_{j}=$ cost at end of year $\mathrm{j} ; R_{\mathrm{j}}=$ revenue at end of year $\mathrm{j} ; i=$ discount or interest rate; $n=$ stand age, in years.

VAE was determined for all four treatments, from age 7 to 15 years. The economic rotation age was defined as the age at which the highest VAE was attained, for an interest rate of $6 \%$ p.a.

\subsection{Sensitivity analysis}

Estimates of project costs and revenues generated VAE values for different candeia harvest ages. This VAE is considered the value most likely to occur, that is, the expected VAE. However, although estimates of costs and revenues were carefully calculated, it is important to question VAE results. In this study, this was done through sensitivity analysis, a method to quantify impact on expected VAE as caused by change in one variable at a

Cerne, Lavras, v. 18, n. 4, p. 695-706, out./dez. 2012 
Table 2 - Costs of implementation and maintenance activities for candeia, according to four treatments.

Tabela 2 - Custos das atividades de implantação e manutenção de candeia para os quatro tratamentos estudados.

\begin{tabular}{|c|c|c|c|c|c|}
\hline \multirow{2}{*}{ Cost items } & \multirow{2}{*}{ Occurrence year } & \multicolumn{4}{|c|}{ Cost value (R $\$$ /ha) } \\
\hline & & $\mathrm{T} 1$ & $\mathrm{~T} 2$ & $\mathrm{~T} 3$ & $\mathrm{~T} 4$ \\
\hline \multicolumn{6}{|l|}{ 1. Implementation } \\
\hline $\begin{array}{l}\text { Soil preparation } \\
\text { (furrow making) }\end{array}$ & 0 & 200.00 & 200.00 & 200.00 & 200.00 \\
\hline Planting labor & 0 & 559.92 & 420.00 & 336.00 & 279.96 \\
\hline Fertilization & & 319.57 & 239.72 & 191.77 & 159.79 \\
\hline Topdressing & 0 & 260.36 & 195.30 & 156.24 & 130.18 \\
\hline Seedlings & 0 & $2,333.00$ & $1,750.00$ & $1,400.00$ & $1,166.50$ \\
\hline Ant control & 0 & 17.00 & 17.00 & 17.00 & 17.00 \\
\hline \multicolumn{6}{|l|}{ 2. Maintenance } \\
\hline $\begin{array}{l}\text { Weed and shrub clearing } \\
\text { (manual) }\end{array}$ & 1 & 210.00 & 210.00 & 210.00 & 210.00 \\
\hline $\begin{array}{l}\text { Weed and shrub clearing } \\
\text { (manual) }\end{array}$ & 2 to 4 & 90.00 & 90.00 & 90.00 & 90.00 \\
\hline Ant control & 1 to 4 & 13.50 & 13.50 & 13.50 & 13.50 \\
\hline Cost of land & 1 to $n$ & 150.00 & 150.00 & 150.00 & 150.00 \\
\hline
\end{tabular}

time, keeping other variables unchanged. To attain that, three scenarios were considered, namely a pessimistic, a most likely and an optimistic scenario, for the variables provided in Table 3. By comparing the effects of different variables on expected VAE, favorable and unfavorable impacts were identified on this economic indicator at different harvest ages.

In addition to analyzing the individual effect of each variable shown in Table 3 on the VAE for different harvest ages, the aggregate effect of these variables on the VAE obtained for each treatment was also analyzed, yet only for the optimal rotation age or economic rotation. For each treatment, 729 VAEs were derived, which is the number of possible combinations resulting from raising number three-the number of scenarios-to the number of variables being used-six in this case. A statistical analysis was performed on the series of $729 \mathrm{VAE}$ values obtained for each treatment.

\section{RESULTS AND DISCUSSION}

\subsection{Determination of the economic rotation age}

Table 4 data reveals that treatment 1 was economically unfeasible for all harvest ages being considered. The high costs involved in virtually every implementation operation of this treatment, relative to other treatments, explain its negative VAE values.

In analyzing the economic feasibility of various management regimes for Pinus taeda L., Acerbi Júnior et al. (2002) observed that even with increased costs (seedlings, fertilizers, etc.) resulting from reduced interrow spacing, proportionately speaking the volume increase is also intensified, making the investment worthwhile. Jones et al. (2010) also observed that high implementation costs in intensive treatments of Pinus were offset by superior growth rates, producing larger volumes of timber for sawmills, the best-valued product class.

This was not the case in this study, however, that is, the volume of candeia timber produced in T1 was slightly higher than in T3 and T4 but lower than in T2. This minor volume gain in $\mathrm{T} 1$ in relation to $\mathrm{T} 3$ and $\mathrm{T} 4 \mathrm{did}$ not suffice to offset the cost increase caused by reduced spacing, making T1 economically unfeasible.

In treatment 1 , with increasing age, the VAE increase is smaller than the previous age, suggesting a point of inflection at age 15 or later, that is, a point where VAE will reach a peak and then will start to decrease. Judging by data tendency, the age of maximum VAE, therefore the economic rotation age, should be 15 or 16 years.

\section{Cerne, Lavras, v. 18, n. 4, p. 695-706, out./dez. 2012}


Table 3 - Variables used in the sensitivity analysis and respective variation intervals for the three scenarios.

Tabela 3 - Variáveis utilizadas na análise de sensibilidade e os respectivos intervalos de variação para os três cenários considerados.

\begin{tabular}{lccc}
\hline \multirow{2}{*}{ Variable } & \multicolumn{2}{c}{ Scenarios } \\
\cline { 2 - 4 } & Pessimistic & Most likely & Optimistic \\
\hline - Interest rate $(\%)$ & $8 \%$ & $6 \%$ & $4 \%$ \\
- Cost of harvest $(\mathrm{R} \$ \mathrm{st})$ & 30.18 & 25.18 & 20.18 \\
- Seedling price $(\mathrm{R} \$ / \mathrm{unit})$ & 0.60 & 0.50 & 0.40 \\
- Price of land (R $/ \mathrm{ha})$ & $3,000.00$ & $2,500.00$ & $2,000.00$ \\
- Timber selling price $(\mathrm{R} \$ / \mathrm{st})$ & 115.00 & 130.00 & 145.00 \\
- Variation in timber volume relative to that obtained by & & & $+10 \%$ \\
Silva $(2009)(\%)$ & $-10 \%$ & $0 \%$ & +100 \\
\hline
\end{tabular}

Table 4 - VAE for different treatments and harvest ages.

Tabela 4 - VAE para os diversos tratamentos e idades de corte.

\begin{tabular}{ccccc}
\hline & \multicolumn{5}{c}{ VAE $(\mathrm{R} \$ / \mathrm{ha})$} \\
\cline { 2 - 5 } Year & $\mathrm{T} 1$ & $\mathrm{~T} 2$ & $\mathrm{~T} 3$ & $\mathrm{~T} 4$ \\
& $(1.5 \times 1.5 \mathrm{~m})$ & $(1.5 \times 2.0 \mathrm{~m})$ & $(1.5 \times 2.5 \mathrm{~m})$ & $(1.5 \times 3.0 \mathrm{~m})$ \\
\hline 7 & -240.21 & -57.69 & -53.87 & 38.78 \\
8 & -185.41 & -19.03 & -22.09 & 63.34 \\
9 & -147.07 & 6.14 & -1.18 & 78.46 \\
10 & -120.11 & 22.69 & 12.23 & 90.96 \\
11 & -101.31 & 32.89 & 20.11 & $\mathbf{9 1 . 6 8}$ \\
12 & -88.52 & 38.26 & 24.13 & 89.76 \\
13 & -80.26 & $\mathbf{4 0 . 1 9}$ & $\mathbf{2 5 . 2 6}$ & 86.01 \\
14 & -75.59 & 39.52 & 24.20 & 80.87 \\
\hline
\end{tabular}

Treatments 2 and 3 had negative VAE values at younger ages but proved economically feasible from 9 and 10 years respectively. Their economic rotation age was 13 years.

The combination of low implementation costs and relatively high volume output made the wider spacing arrangement $(1.5 \times 3.0 \mathrm{~m})$ economically superior to the others. It is therefore assumed that spacing arrangements above $1.5 \times 3.0 \mathrm{~m}$ might allow even better profits, subject to further studies intended to detect the maximum interrow spacing to be used in candeia stands.

\subsection{Sensitivity analysis}

Figure 1 provides VAE sensitivity to changes in timber price at different harvest ages and treatments. Most likely scenarios are represented by squares. Optimistic scenarios are represented by the upper end of lines, above squares, while pessimistic scenarios are represented by the lower end of lines, below squares.

Irrespective of treatment, increases in timber price tend to reduce economic rotation age. In treatment 1 , economic rotation occurs at age 15 years in the pessimistic and most likely scenarios, and at age 14 years in the optimistic scenario. In treatments 2 and 3, economic rotation occurs at ages 14, 13 and 12 years, respectively in the pessimistic, most likely and optimistic scenarios, while in treatment 4 rotation occurs at 13, 12 and 11 years, following the same order of scenarios.

Lopes (1990) mathematically demonstrated that proportional variations in the price of eucalyptus timber

Cerne, Lavras, v. 18, n. 4, p. 695-706, out./dez. 2012 
T1

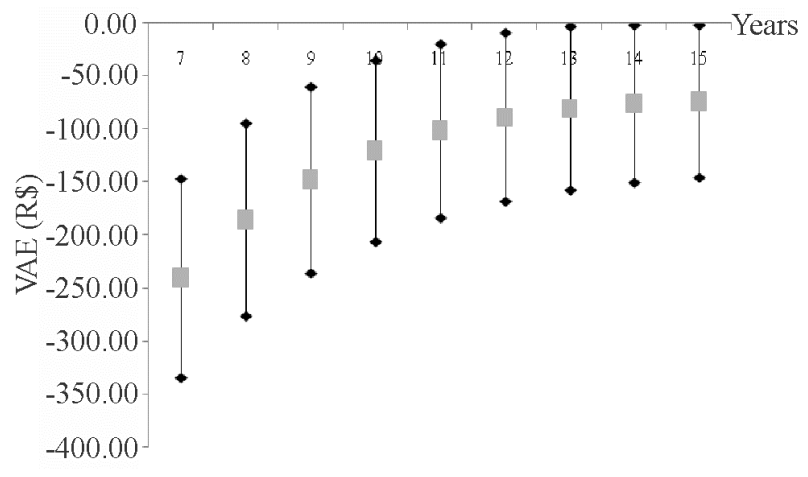

T3

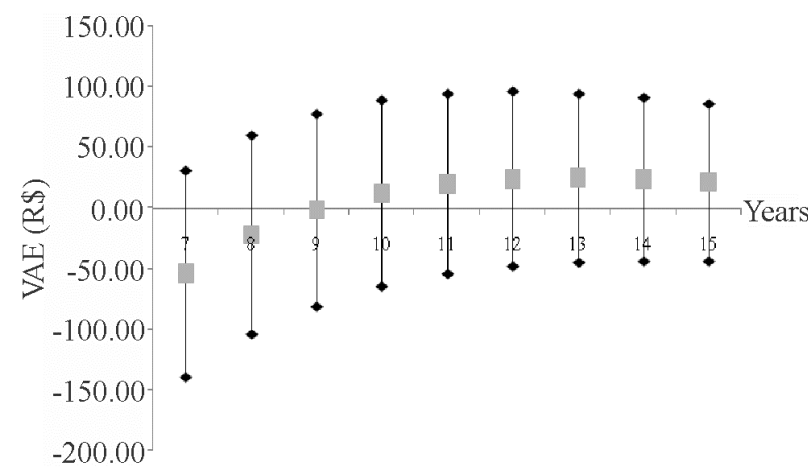

$\mathrm{T} 2$

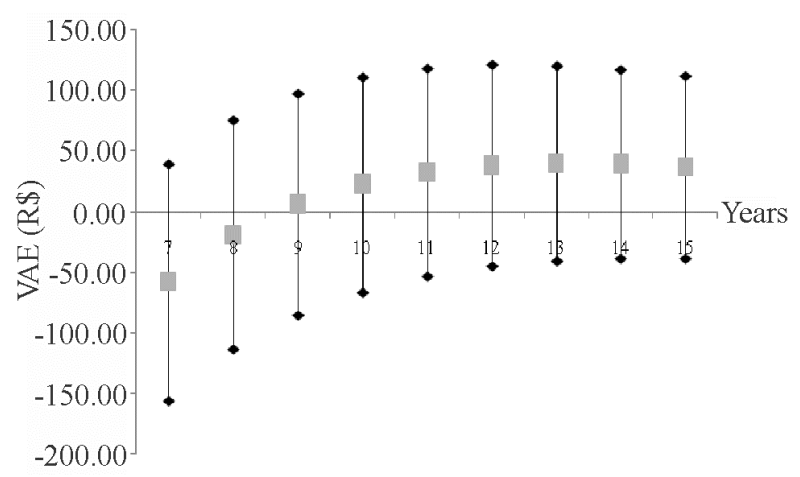

$\mathrm{T} 4$

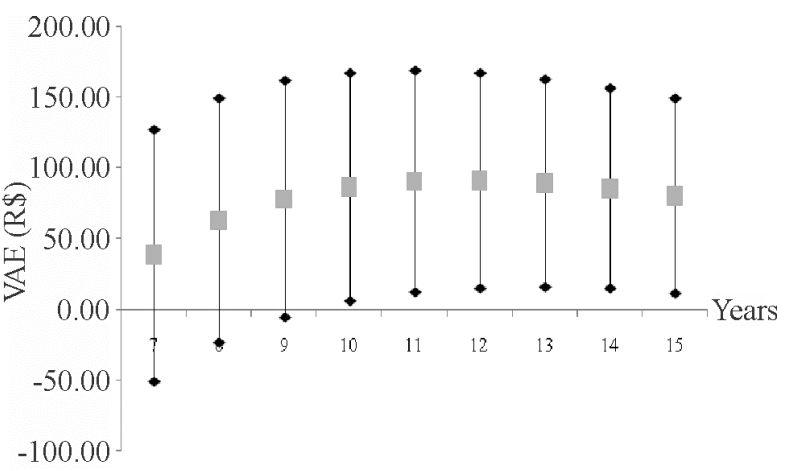

Figure 1 - VAE sensitivity $(\mathrm{R} \$)$ to changes in timber price.

Figura 1 - Sensibilidade do $\operatorname{VAE}(R \$)$ a alterações no preço da madeira.

implied directly proportional variations in optimal rotation ages, for interest rates lower than the growth rates of the forest. For interest rates higher than the growth rates of the forest, variations in optimal rotation age were inversely proportional, and finally, when interest rates equalized, no influence was noted on optimal rotation ages.

Rodriguez et al. (1997) argue that increase in timber price makes the activity more attractive, causing the reduction in rotation age to allow accelerated cycles and the possibility of shorter reinvestment periods.

As was expected, reduced interest rates improved treatment profitability in all rotation ages being analyzed. For a $4 \%$ p.a. rate, even the worst treatment (T1) proves economically feasible if the rotation age is 9 years or more (Figure 2).

According to Rodriguez et al. (1997), that occurs because increasing interest rate raises the cost of capital, overburdening the project over time and consequently forcing a shortened economic rotation.

Cerne, Lavras, v. 18, n. 4, p. 695-706, out./dez. 2012
Higher interest rates tend to shorten the economic rotation age. For instance, in treatment 4 the optimal rotation age goes from 14 years when the interest rate is $4 \%$ p.a. to 10 years when the interest rate is $8 \%$ p.a.

Lopes (1990) mathematically demonstrated that proportional variations in discount rate imply inversely proportional variations in optimal rotation ages for eucalyptus stands. Several authors reported similar results to the findings of Lopes (1990), including Ângelo et al. (2009), Hoffmann and Berger (1973), Orois and Chang (2004) and Penttinen (2006).

Figure 3 illustrates VAE sensitivity to changes in volume output. Treatment 1 is not economically feasible in any age or level of volume output. Other treatments proved economically feasible in all ages, provided that the volume output is $10 \%$ higher than in the most likely scenario. Treatment 4 is distinguished from the others in that it is feasible in almost all scenarios, except for the pessimistic scenario, but only for age 7 years. Increases in volume output tend to shorten the economic rotation age. For 
$\mathrm{T} 1$

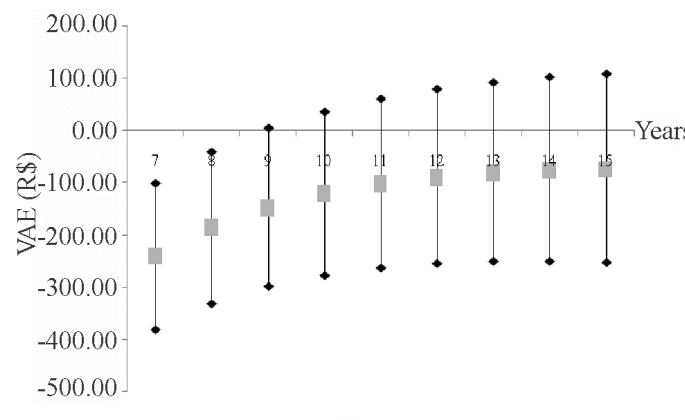

T3

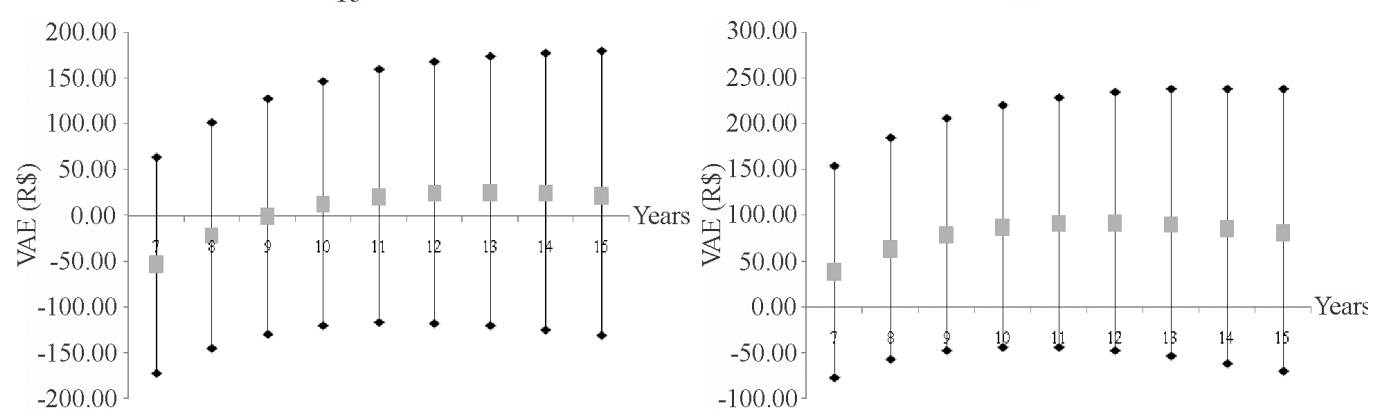

Figure 2 - VAE sensitivity $(\mathrm{R} \$)$ to changes in interest rate.

Figura 2 - Sensibilidade do VAE $(R \$)$ a alterações na taxa de juros.
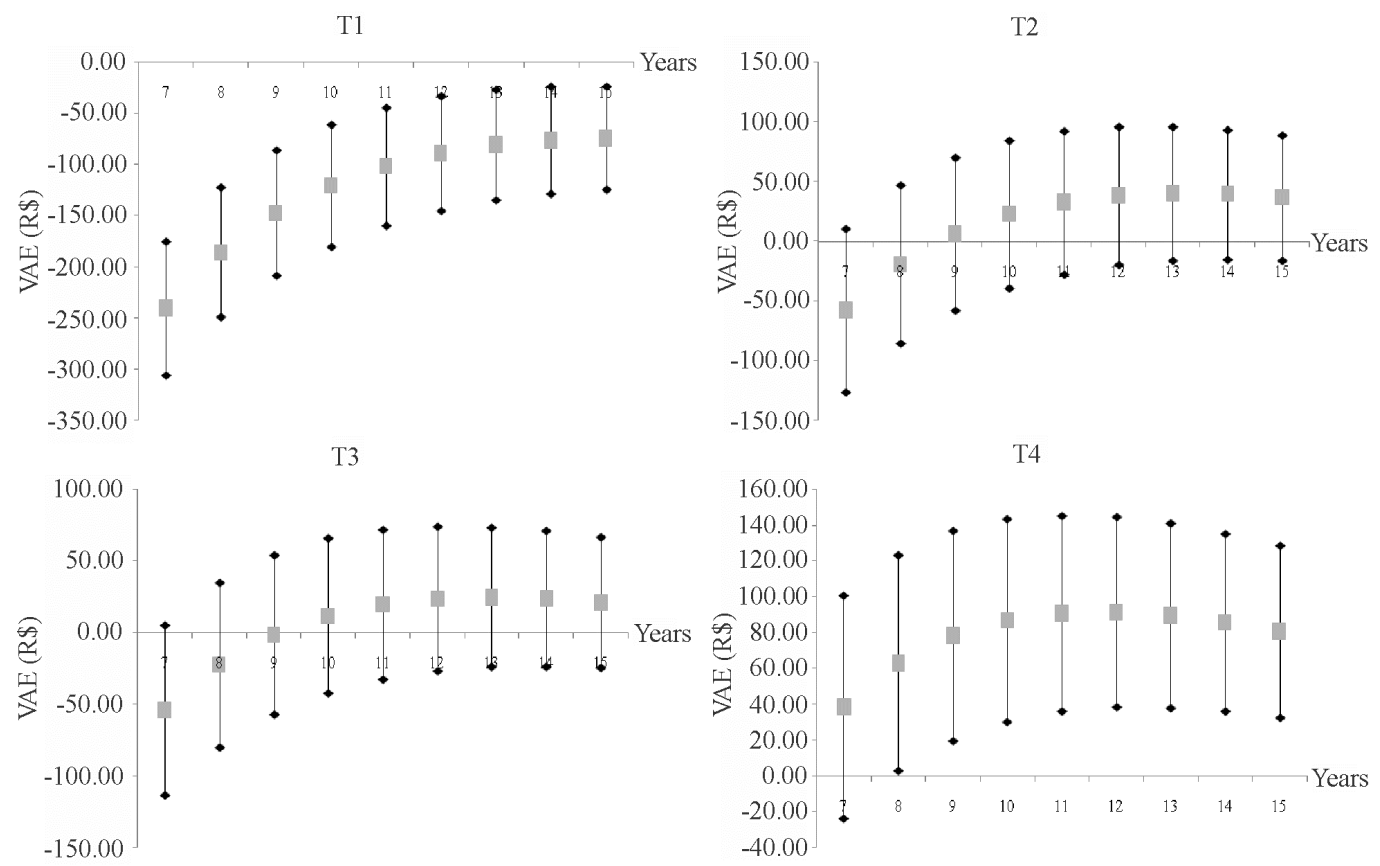

Figure 3 - VAE sensitivity ( $R$ \$) to changes in volume output.

Figura 3 - Sensibilidade do VAE $(R \$)$ a alterações no volume. 
instance, in treatment 3 rotation occurs at 14, 13 and 12 years, respectively in pessimistic, most likely, and optimistic scenarios. Lopes (1990) mathematically demonstrated this reverse trend between volume output and rotation age for eucalyptus stands. Mola-Yudego and Aronsson (2008) found similar results with willow stands and claimed that good initial growth levels can encourage producers to reduce the rotation cycle, while low volume outputs contribute to prolong rotation, when looking to maximize profitability.

Figure 4 reveals that treatment 1 is not economically feasible at any age and harvest cost level being analyzed. Treatments 2 and 3 proved economically feasible from year 8 and where a harvest cost of $\mathrm{R} \$ 20.18 /$ st was considered. Treatment 4 is economically feasible in all ages and cost levels being analyzed.

In treatments 1 and 3 , the economic rotation age remained unchanged with variations in cost of harvest, while in treatments 2 and 4 the rotation age tended to decrease with reduced cost of harvest. For instance, in treatment 2 the optimal rotation age went from 14 to 13 years when cost of harvest fell from $\mathrm{R} \$ 30.18$ /st to $\mathrm{R} \$ 25.18 /$ st, while in treatment 4 the rotation age went from 12 to 11 years when cost decreased from $\mathrm{R} \$ 25.18$ to $\mathrm{R} \$ 20.18$.

Lopes (1990) found that proportional variations in exploration cost led to directly proportional variations changes in the optimal rotation age of the stand, when the interest rate exceeded the growth rate of the forest. For interest rates lower than the forest growth rate, variations in optimal rotation age were inversely proportional and, finally, when rates equalized no influence was noted on optimal rotation ages.

Figure 5 illustrates VAE sensitivity to changes in the price of candeia seedlings. Treatment 2 proved economically feasible in all ages, provided that seedling price is $\mathrm{R} \$ 0.40$. Treatment 3 is economically feasible from year 8 and when seedling price is $\mathrm{R} \$ 0.40$. Treatment 4 proved economically feasible for all ages and seedling prices,
$\mathrm{T} 1$

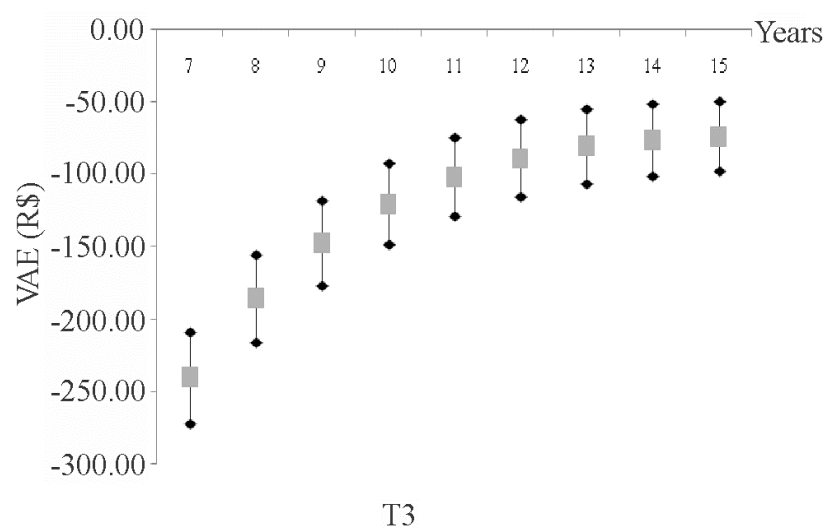

$\mathrm{T} 2$

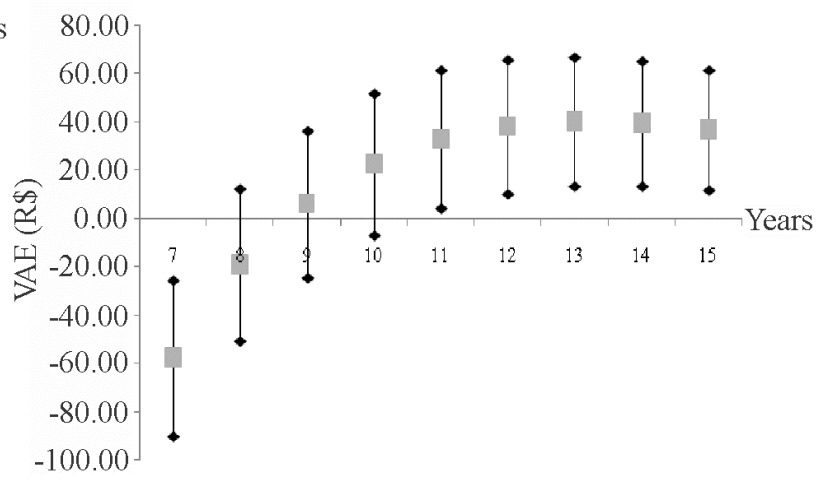

$\mathrm{T} 4$

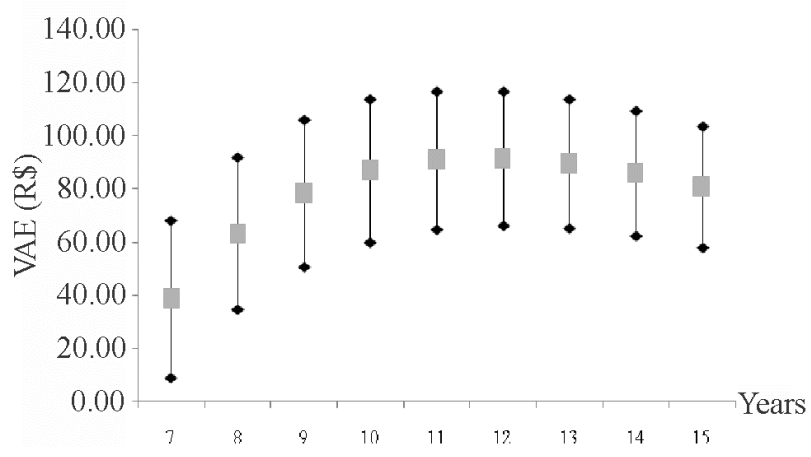

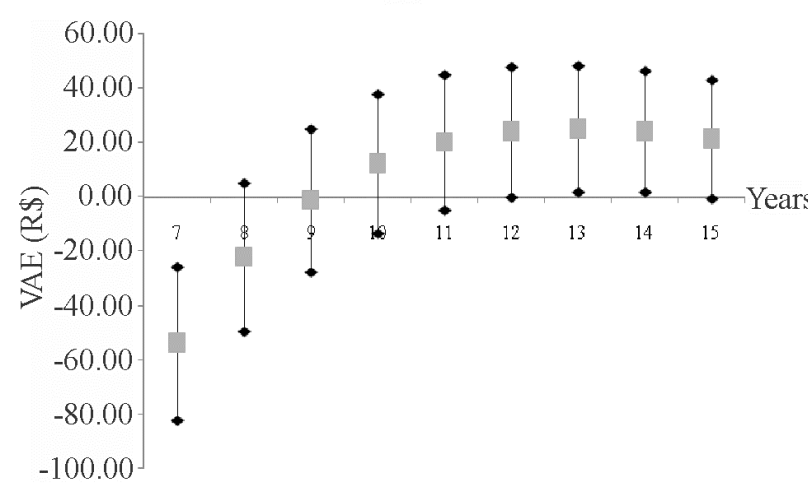

Figure 4 - VAE sensitivity (R\$) to changes in cost of harvest.

Figura 4 - Sensibilidade do VAE (R\$) a alterações no custo de colheita.

Cerne, Lavras, v. 18, n. 4, p. 695-706, out./dez. 2012 
$\mathrm{T} 1$

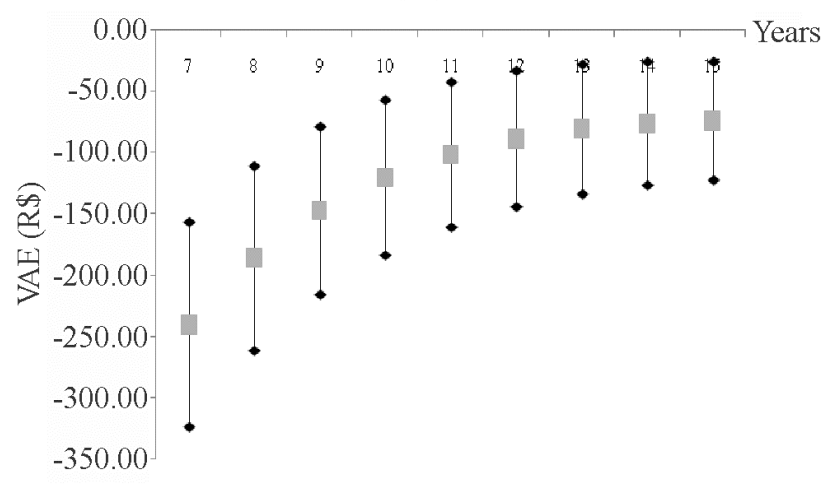

T3

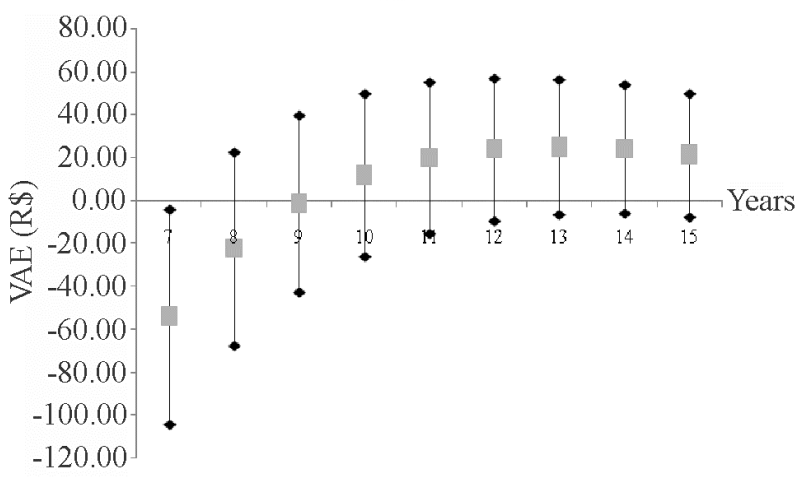

$\mathrm{T} 2$

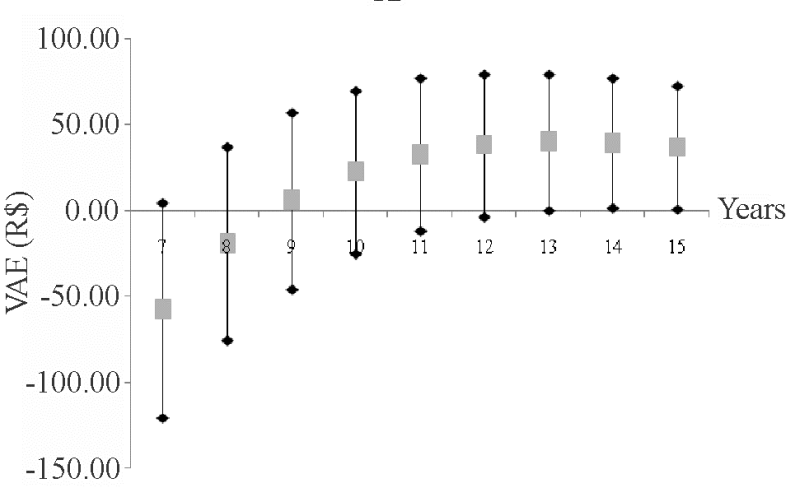

T4

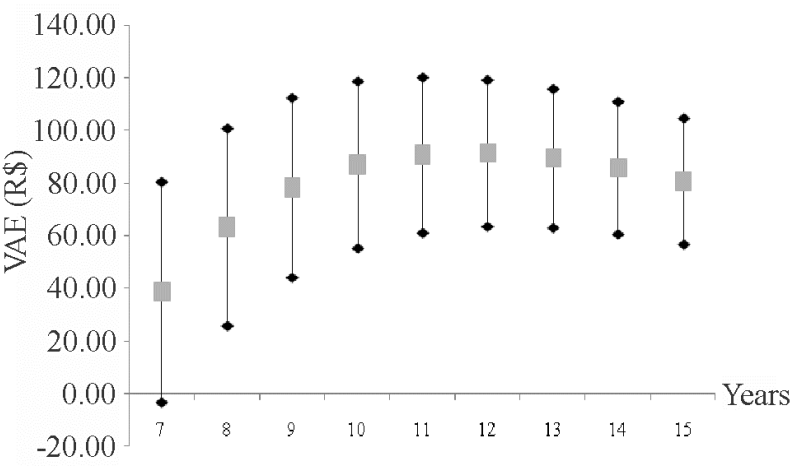

Figure 5 - VAE sensitivity ( $\mathrm{R} \$$ ) to changes in seedling price.

Figura 5 - Sensibilidade do VAE (R\$) a alterações no preço da muda.

except age 7, in which the VAE is negative when the seedling price is $\mathrm{R} \$ 0.60$.

Irrespective of treatment, increases in seedling price tend to prolong economic rotation. In treatment 1 , economic rotation occurs at 15 years in the pessimistic and most likely scenarios, and at 14 years in the optimistic scenario. In treatments 2 and 3, economic rotation occurs at 14, 13 and 12 years, respectively in pessimistic, most likely and optimistic scenario. In treatment 4 , the economic rotation age is 12 years in the pessimistic and most likely scenarios, and 11 years in the optimistic scenario.

In a study with eucalyptus, Rodriguez et al. (1997) observed that, other variables remaining unchanged, increases in implementation cost resulted in prolonged economic rotations. According to these authors, this occurs because as the value of initial investment increases, it is financially more interesting to prolong rotation, thereby expecting that a larger volume output will offset the higher initial investment.
Figure 6 illustrates VAE sensitivity to changes in cost of land. Treatment 1 is not economically feasible at any age or cost level being analyzed. Treatment 4 , on the other hand, is economically feasible in all three scenarios. Treatments 2 and 3 proved economically feasible from year 8 and when the price of land was $\mathrm{R} \$ 2,000.00$.

The economic rotation age of the various treatments was not affected by changes in cost of land.

\subsection{Combined three scenarios}

The descriptive statistics of treatment distributions are illustrated in Table 5. A greater range and a higher standard deviation were found in treatment 1 , respectively with values $\mathrm{R} \$ 817.80$ and $\mathrm{R} \$ 172.78$. In treatments 1,3 and 4 the distribution of VAE is virtually symmetrical, with expected values being very close to the values of the most likely scenario. In treatment 2 , on the other hand, the value of the most likely scenario was $\mathrm{R} \$ 40.19$, while the expected value was $\mathrm{R} \$ 68.74$, demonstrating that VAEs are slightly

Cerne, Lavras, v. 18, n. 4, p. 695-706, out./dez. 2012 
$\mathrm{T} 1$

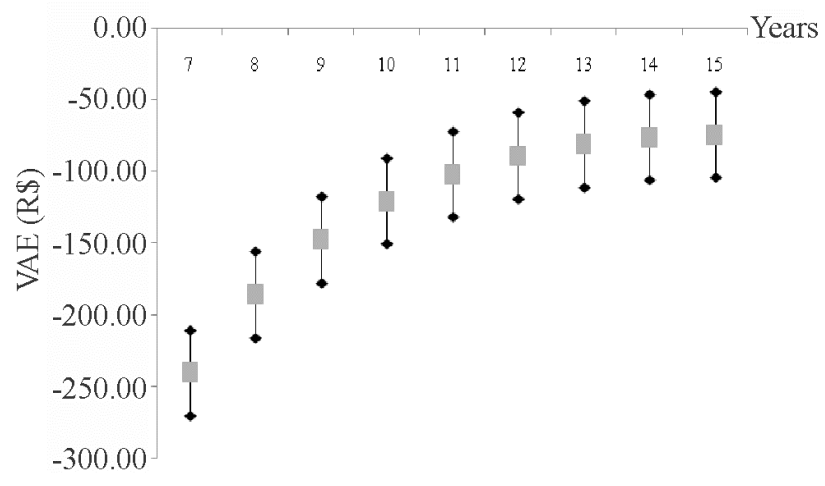

T3

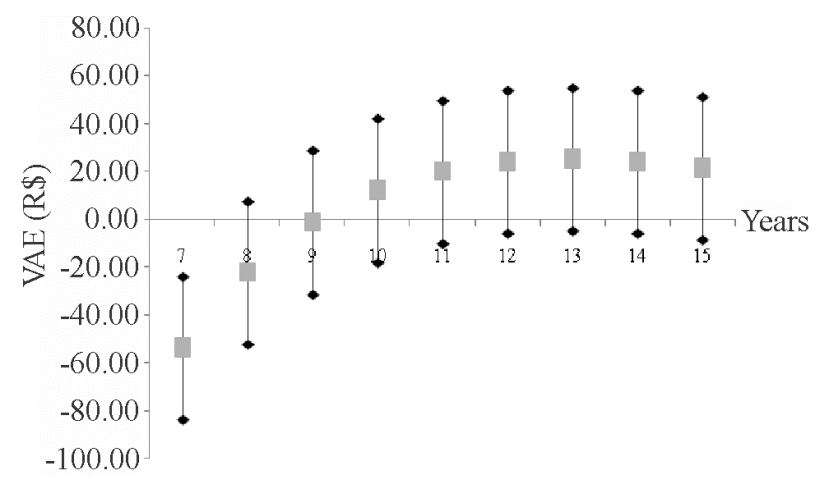

$\mathrm{T} 2$

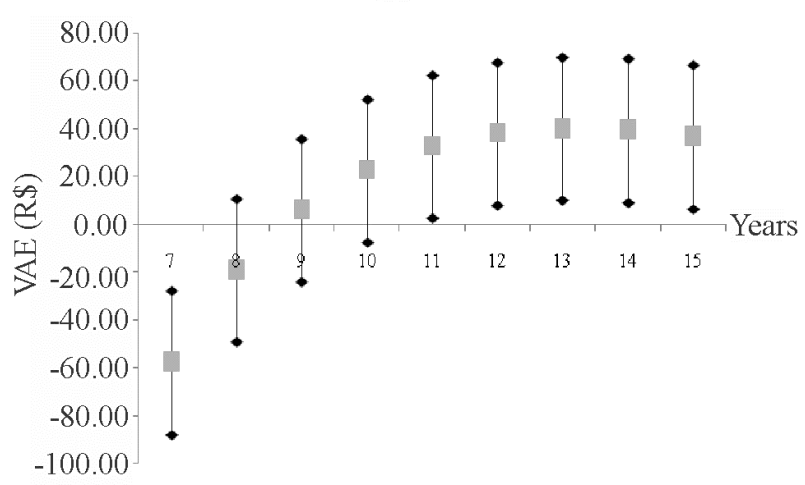

$\mathrm{T} 4$

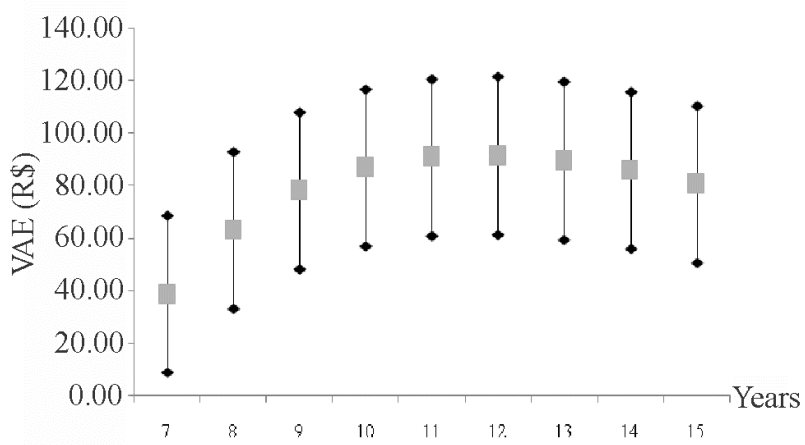

Figure 6 - VAE sensitivity (R\$) to changes in cost of land.

Figura 6 - Sensibilidade do VAE $(R \$)$ a alterações no custo da terra.

Table 5 - Descriptive statistics of distributions for four treatments.

Tabela 5 - Estatísticas descritivas das distribuições dos quatro tratamentos.

\begin{tabular}{lcccc}
\hline Treatment & $\mathrm{T} 1$ & $\mathrm{~T} 2$ & $\mathrm{~T} 3$ & $\mathrm{~T} 4$ \\
\hline Maximum VAE & $\mathrm{R} \$ 354.52$ & $\mathrm{R} \$ 459.44$ & $\mathrm{R} \$ 394.87$ & $\mathrm{R} \$ 465.02$ \\
Minimum VAE & $\mathrm{R} \$-463.28$ & $\mathrm{R} \$-250.34$ & $\mathrm{R} \$-311.36$ & $\mathrm{R} \$-246.52$ \\
VAE of the most likely scenario & $\mathrm{R} \$-73.59$ & $\mathrm{R} \$ 40.19$ & $\mathrm{R} \$ 25.26$ & $\mathrm{R} \$ 91.68$ \\
Mean or expected VAE & $\mathrm{R} \$-71.33$ & $\mathrm{R} \$ 68.74$ & $\mathrm{R} \$ 27.36$ & $\mathrm{R} \$ 93.29$ \\
Standard deviation of VAE & $\mathrm{R} \$ 172.78$ & $\mathrm{R} \$ 159.11$ & $\mathrm{R} \$ 145.20$ & $\mathrm{R} \$ 144.32$ \\
Coefficient of variation of VAE & - & 2.31 & 5.31 & 1.55 \\
\hline
\end{tabular}

concentrated on the left of the frequency distribution. This concentration can be better viewed in Figure 7, which provides the frequency histogram of VAEs for different treatments.

Treatment 4 had the lowest standard deviation and coefficient of variation values, suggesting that this treatment is less likely to have a negative VAE and consequently be economically unfeasible. According to Lapponi (2007), coefficient of variation is a risk measure that allows comparisons between projects. This measure was used to compare treatments with positive means, hence it not being calculated for T1, as illustrated in Table 5.

Figure 7 also reveals that treatment 4 had the largest number of positive VAEs, a total of 519, which accounts for $71.19 \%$ of the combinations. Treatments 2,3 and 1 come

Cerne, Lavras, v. 18, n. 4, p. 695-706, out./dez. 2012 

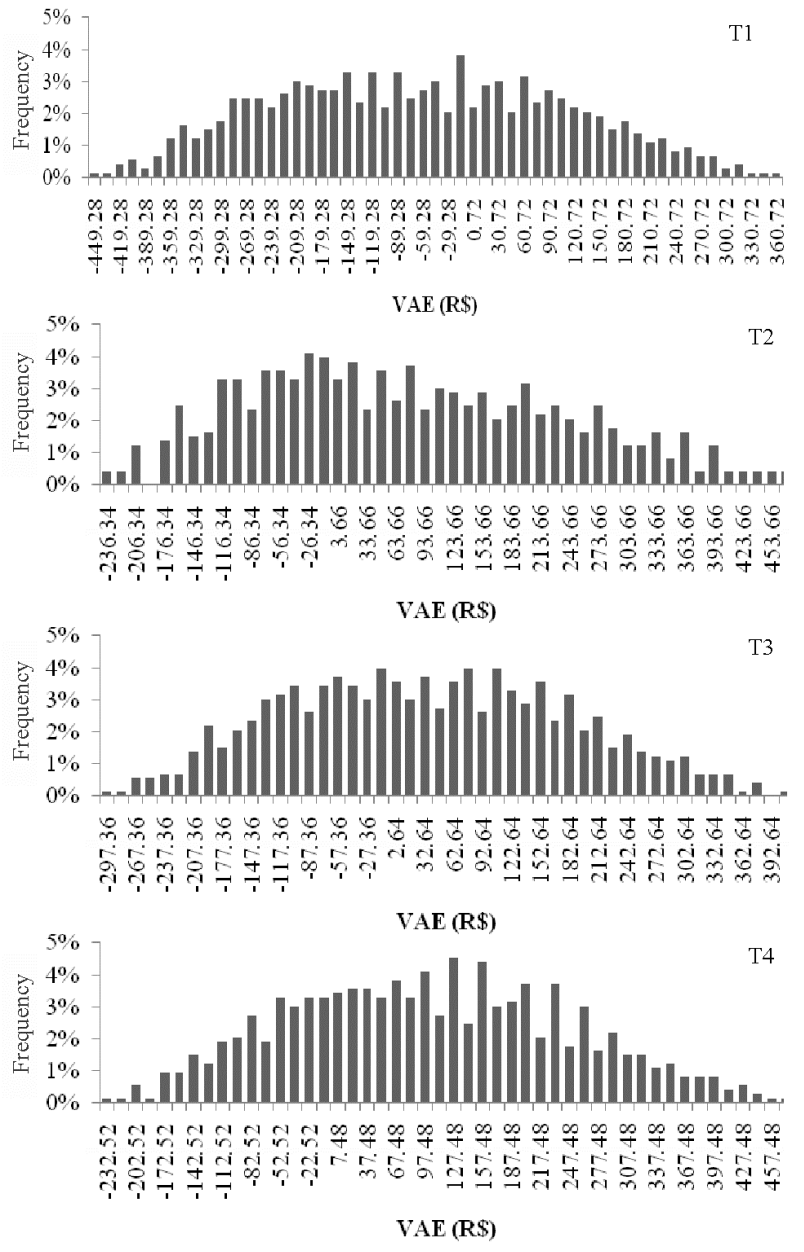

Figure 7 - Frequency histogram of VAEs in each treatment.

Figura 7 - Histograma de freqüência dos VAEs nos tratamentos.

next, respectively with $60.63 \%, 55.14 \%$ and $36.08 \%$ of positive VAEs. This demonstrates yet again the superiority of treatment 4 against the others.

\section{CONCLUSIONS}

Cultivation of nonnative candeia stands is profitable when spacing arrangements are $1.5 \times 2.0 \mathrm{~m}$ or more. Spacing arrangements denser than that are economically unfeasible for the ages being analyzed.

Among the spacing arrangements being studied, $1.5 \times 3.0 \mathrm{~m}$ was found the most profitable and less risky.

The economic rotation age for candeia is 15 years using $1.5 \times 1.5 \mathrm{~m}$ spacing; 13 years using $1.5 \times 2.0 \mathrm{~m}$ and 1.5 $\mathrm{x} 2.5 \mathrm{~m}$ spacing; and 12 years using $1.5 \times 3.0 \mathrm{~m}$ spacing.
Proportional variations in timber price, volume output and interest rate implied inversely proportional variations in economic rotation age for the spacing arrangements being studied. Conversely, proportional variations in seedling price implied directly proportional variations in the rotation. Changes in the cost of harvest also implied directly proportional variations in the economic rotation age for spacing arrangements $1.5 \times 3.0 \mathrm{~m}$ and $1.5 \mathrm{x}$ $2.0 \mathrm{~m}$ but did not affect rotation age for spacing arrangements $1.5 \times 1.5 \mathrm{~m}$ and $1.5 \times 2.5 \mathrm{~m}$. Finally, changes in land price did not affect economic rotation for any of the spacing arrangements.

\section{ACKNOWLEDGEMENTS}

The first author wishes to thank CAPES for granting a scholarship, and the second author wishes to thank CNPq for granting a scholarship based on research productivity, as well as FAPEMIG for providing financial support through the PPMIV program (CAG - PPM - 00286$10)$.

\section{REFERENCES}

ACERBI JÚNIOR, F. W.; SCOLFORO, J.R.S.; OLIVEIRA, A.D.; MAESTRI, R. Modelo para a prognose do crescimento e da produção e análise econômica de regimes de manejo para Pinus taeda L. Revista Árvore, Viçosa, v. 26, n. 6, p. 699713, nov./dez. 2002.

ÂNGELO, H.; SILVA, V.S.M.; SOUZA, A.N. GATTO, A.C.. Aspectos financeiros da produção de teca no estado de Mato Grosso. Revista Florestal, Curitiba, v. 39, n. 1, p. 23-32, jan./mar. 2009.

FIGUEIREDO, E. O.; OLIVEIRA, A. D. de; SCOLFORO, J. R. S. Análise econômica de povoamentos não desbastados de Tectona grandis L.f., na microrregião do baixo Rio Acre.

Cerne, Lavras, v. 11, n. 4, p. 342-350, out./dez. 2005.

GARDINGEN, P. R. van; MCLEISHA, M. J.; PHILLIPS, P. D. Financial and ecological analysis of management options for logged-over Dipterocarp forests in Indonesian Borneo. Forest Ecology and Management, Amsterdam, v. 183, n. 1/3, p. 129, Sept. 2003.

HOFFMANN, R.; BERGER, R. Determinação da idade ótima de corte de povoamentos de Eucalyptus. Boletim do Instituto de Pesquisas e Estudos Florestais, Piracicaba, n. 7, p. 4969, 1973. 
JONES, P. D.; GRADO, S. C.; DEMARAIS, S. Financial analysis of intensive pine plantation establishment. Journal of Forest Economics, Jena, v. 16, n. 2, p. 101-112, Feb. 2010.

LAPPONI, J. C. Projetos de investimentos na empresa. Rio de Janeiro: Elsevier, 2007. 332 p.

LOPES, H. V. S. Análise econômica dos fatores que afetam a rotação de povoamentos de eucaliptos. 1990. $188 \mathrm{f}$. Dissertação (Mestrado em Ciências Florestais) - Universidade Federal de Viçosa, Viçosa, 1990.

OLIVEIRA, A. D. de; RIBEIRO, I.S.A.; SCOLFORO; J.R.S.; MELLO, J.M. de; REZENDE, J.L.P. de. Economic analysis of sustainable management of candeia. Cerne, Lavras, v. 16, n. 3, p. 335-345, jul./set. 2010.

OROIS, S. S.; CHANG, S. J. Optimal residual growing stock and cutting cycle in mixed uneven-aged maritime pine stands in Northwestern Spain. Forest Policy and Economics, Amsterdam, v. 6, n. 1, p. 145-152, Mar. 2004.

PENTTINEN, M. J. Impact of stochastic price and growth processes on optimal rotation age. European Journal of Forest Research, New York, v. 125, n. 4, p. 335-343, Oct. 2006.

PÉREZ, J. F. M. Sistema de manejo para candeia (Eremanthus erythropappus (DC.) MacLeish). 2001. 71 p. Dissertação (Mestrado em Produção Florestal) - Universidade Federal de Lavras, Lavras, 2001.

REZENDE, J. L. P. de; OLIVEIRA, A. D. de. Análise econômica e social de projetos florestais. 2. ed. Viçosa, MG: UFV, 2008. 386 p.

REZENDE, J. L. P. de; OLIVEIRA, A. D. de; RODRIGUES, C. Efeito dos tributos no custo de produção, na rotação e na reforma de Eucalyptus spp. Cerne, Lavras, v. 11, n. 1, p. 7083, jan./mar. 2005.
RODRIGUES, E. R.; CULLEN JUNIOR, L.; BELTRAME, T.P.; MOSCOGLIATO, A.V.; SILVA, I.C. da. Avaliação econômica de sistemas agroflorestais implantados para recuperação de reserva legal no pontal do Paranapanema, São Paulo. Revista Árvore, Viçosa, v. 31, n. 5, p. 941-948, set./out. 2007.

RODRIGUEZ, L. C. E.; BUENO, A. R. S.; RODRIGUES, F. Rotações de Eucaliptus mais longas: análise volumétrica e econômica. Scientia Florestalis, Piracicaba, v. 51, n. 1, p. 1528, jun. 1997.

SCOLFORO, J. R. S.; HOSOKAWA, R. T. Avaliação da rotação econômica para Pinus caribeae var. hondurensis sujeito a desbastes. Revista Árvore, Viçosa, v. 18, n. 1, p. 3344, jan./mar. 1992.

SILVA, C. P. de C. Crescimento e produção da candeia em plantio sujeito a diferentes espaçamentos e podas. 2009. 132 p. Dissertação (Mestrado em Florestas de Produção) Universidade Federal de Lavras, Lavras, 2009.

SIREGAR, U. J.; RACHMI, A.; MASSIJAVA, M.Y; ISHIBASHI, N.; ANDO, K. Economic analysis of sengon (Paraserianthes falcataria) community forest plantation, a fast growing species in East Java, Indonesia. Forest Policy and Economics, Amsterdam, v. 9, n. 7, p. 822-829, Apr. 2007.

SOARES, T. S.; SILVA, M.L.; GAMA, J.R.V.; CARVALHO, R.M.M.A.; VALE, R.S. Avaliação econômica de plantações de eucalipto submetidas a desbaste. Revista Árvore, Viçosa, v. 27, n. 4, p. 481-486, jul./ago. 2003.

WHITTOCK, S. P. van; GREAVES, B. L. A.; APIOLAZA, L. A. A cash ûow model to compare coppice and genetically improved seedling options for Eucalyptus globulus pulpwood plantations. Forest Ecology and Management, Amsterdam, v. 191, n. 1/3, p. 267-274, Mar. 2004.

YUH-CHING, H. Contabilidade e finanças para não especialistas. São Paulo: Pearson Prentice-Hall, 2003. 288 p. 